\title{
Total Factor Productivity Growth and Returns from Mango Research in Konkan Region of Maharashtra
}

\author{
Amruta S. Jangale ${ }^{1 *}$, R. B. Hile ${ }^{1}$ and P. C. Rathod ${ }^{2}$ \\ ${ }^{1}$ Department of Agricultural Economics, PGI, MPKV, Rahuri, Maharashtra \\ ${ }^{2}$ College of Agriculture Nagpur, Maharashtra \\ *Corresponding author
}

\section{A B S T R A C T}

\section{Keywords}

Total Factor Productivity, Return to investment, EVMP

\section{Article Info}

Accepted: 12 December 2020 Available Online: 10 January 2021
Productivity growth in horticulture is essential for the development of the sector. This paper has reviewed the developments in mango productivity related to the Konkan Region Mahrashtra. The TFP growth and its contribution in production growth have been summarised for Konkan region of Maharashtra over the past two decades. The total factor productivity indices of mango estimated using Tornqvist index for study period 1998-99 to 2017-18. TFP index was promising for the study period; it indicated that the inputs were efficiently allocated in mango plantation. TFP increased at 2.93 per cent per annum. During the same period, output index grew by 2.05 per cent per annum and input index declined at the rate of 0.86 per cent per annum. The improvement in the total factor productivity was may be due to non-input factor such research investment and extension efforts. The results indicate that research investment (00.18), rainfall (0.55), road density (0.63) and rural literacy (2.05) have significantly contributed to TFP growth in mango. Estimated value of marginal returns was 53.25 it indicates that an additional investment of one rupee in mango research generated additional income of ₹ 53.25. The inverse of TFP elasticity to research gives flexibility to research investment. The estimated value was 5.56 which mean that to achieve one per cent growth in TFP, the investments in research need to be increased by 5.56 per cent for mango in Konkan region of Maharashtra. This paper would provide useful information to the people interested in doing research on these issues. Some of the concerns raised in this paper on total factor productivity would provide direction for future research in this area.

\section{Introduction}

TFP growth measures the increase in output i.e. not accounted for by the increase in total inputs. Thus total factor productivity index that measure the growth in net output i.e. not accounted for by the growth in basic factor input such as land, labour, capital. It is superior to partial approach as it is composite measure of productivity, which related output to all inputs, simultaneously. There are two concepts of productivity: partial productivity and total factor productivity. Partial productivity measures the contribution of one factor (say labour or capital) to output growth keeping the other factors constant. As such 
we have the concepts of labour productivity, capital productivity, which estimate the efficiency of resource use. But, partial productivity does not truly reflect whether it (productivity growth) is because of more use of inputs or improvement in the efficiency of their use or technology improvement. Further, it also ignores time, secondary products, inputs other than land, labour and capital and externalities, all of which should be included in a sustainability measure (Barnell et al., 1995). Therefore the interest shifts to the Total Factor Productivity (TFP). Any growth in output that is not explained by some index of input growth is attributed to changes in technology or more broadly Total Factor Productivity. TFP measures the net growth of output per unit of total inputs. As such, its level is determined by how efficiently and intensely the inputs are utilized in production. Thus, TFP growth is a catch-all measure that captures changes in efficiency in addition to pure technical change in the sense of shifts in the production function. TFP is regarded as the more accurate productivity measure than the partial productivity measure.

Mango (Mangifera indica Linn) is the most important fruit of India and is known as "King of fruits", owing to its nutritional richness, unique taste, pleasant aroma and its religious, medicinal importance and tasted by all corners of world. It is considered as 'National fruit of India' and is believed to be originated in South East Asia, Indo Burma region, in the foot hills of the Himalayas. It has been variously called Amra, Chuta, Rasala, Sahakara, Atisourabha in ancient Sanskrit literature and the tree has been described as Kalpa-Vriksha or the wishgranting. It is the most important tropical fruit of the world. It can also be grown in the subtropical conditions and up to elevations of 1400 meters above the mean sea level. The optimum temperature range for growth is 18 to $35{ }^{\circ} \mathrm{C}$ and it can tolerate temperatures as high as $48{ }^{\circ} \mathrm{C}$. It can survive in areas having an average annual rainfall ranging from 250 $\mathrm{mm}$ to $2000 \mathrm{~mm}$. Loamy, alluvial, well drained, aerated and deep soils rich in organic matter with a $\mathrm{pH}$ range of 5.5 to 7.5 are ideal for mango cultivation. The total world production of Mango is 55.4 MT in 2018. It is commercially grown in more than 111 countries but nowhere it is as greatly valued as in India where $40 \%$ of area under fruit crops is only under mango. India is the largest producer of mango in the world, and ranks first in area and production. The total production of mango in India is 21.8 MT from about 2.516 million ha area. India contributes about $64 \%$ of the world mango production. In Konkan, 1.10 lakh ha productive area was under mango cultivation having annual production of 2.6 lakh MT. The productivity of mango in Konkan is about 2.5 to 3.0 MT ha-1, which is about three times less than the average productivity of the country.

In Konkan region of Maharashtra DBSKKV, Dapoli University has released remarkable vaeieties of mango In Maharashtra at RFRS, Vengurla. These varieties are responsible for the socio economic and political changes in the farming community's in Konkan region of Maharashtra. In this context, it is imperative to examine the total factor factor productivity of mango rsearch over the years, especially its output and inputs in terms of quantity and prices to estimate the returns and investment, etc. The main objective of the research paper is to analyze the growth of total factor productivity of the mango crop in the Konkan region of Maharashtrastate.

\section{Materials and Methods}

\section{Selection of research stations and study area}

Maharashtra state is sub-tropical region of the country. Konkan region of Maharashtra state 
was selected for the study observing the agroclimatic suitability of the region for the mango plantation and also it comprises mango producing district of the state viz., Sindhudurg, Ratnagiri, Raigad, and Thane. Besides, a separate Agricultural university viz., Dr. Balasaheb Sawant Konkan Krishi Vidyapeeth, Dapoli has been established in 1972. Under this university, Separate research stations have been conducting crop specific research for different horticultural crops of the region. To have an ease in collection of data on investment on crop specific research, the Konkan region of Maharashtra was selected purposively for the study.

In Konkan region of Maharashtra area under mango is dominantly covered by the varieties released by Regional fruit research station, Vegurla district Sindhudurg, a leading research station since 1957 under Dr. Balasaheb Sawant Konkan Krishi Vidyapeeth, Dapoli. So, Regional fruit research station, Vegurla was purposively selected for the study. Secondary data was used for the study. The data regarding expenditure and outcome on horticulture research on mango crop was collected from the financial records of research station.

\section{Nature and Sources of Data}

The data regarding research investment and outcome of mango was taken from RFRS, Vengurla research unit. The data on per hectare input use and output and their prices were taken from the official records of the cost of the cultivation scheme of Dr. Balasaheb Sawant Konkan Krishi Vidyapeeth, Dapolifor the last 20 years.

\section{Crop covered}

Mango crop was purposively selected for study.

\section{Period of Study}

In the present study, looking to the availability of data, a period of 20 years, i.e. 1998-99 to 2017-18 has been considered. The time series data has been divided into to two periods viz., Period I - (1998-99 to 2007-08) and Period - II (2008-09 to 2017-18) to see whether significant swing has been taken in the economy due to Horticultural Research and Development Policies.

\section{Research tools}

For the present study three approaches were used viz.,
(i) Total factor productivity
(ii) Production function approach

\section{Total Factor Productivity methodologies of measuring TFP}

TFP indices computed as follows, Total Output Index

$$
\begin{aligned}
& (\mathrm{TOI})=\text { TOIt } / \text { TOIt }-1=\prod \mathrm{j}(\mathrm{Qjt} / \mathrm{Q} \mathrm{jt}-1)(\mathrm{Rjt}+\mathrm{Rjt}- \\
& \text { 1) } 1 / 2
\end{aligned}
$$

\section{Total input index}

$$
(\mathrm{TII})=\mathrm{TII}_{\mathrm{t}} / \mathrm{TII}_{\mathrm{t}-1}=\prod_{\mathrm{j}}(\mathrm{Xjt} / \mathrm{Xjt}-1)^{(\mathrm{Sjt}+\mathrm{Sjt}-1) 1 / 2}
$$

Total factor productivity index (TFPI) of $t^{\text {th }}$ year is 100 times the ratio of TOI, to the TII and is given by,

$\mathrm{TFPI}_{\mathrm{t}}=\left(\mathrm{TOI}_{\mathrm{t}} / \mathrm{TII}_{\mathrm{t}}\right) \times 100$

Input price index is given by,

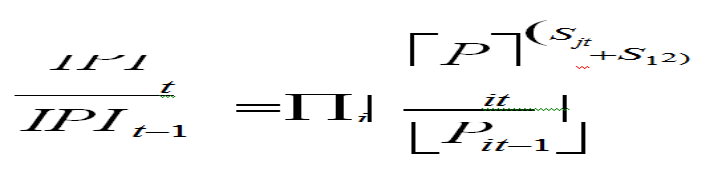

Where, 


\begin{tabular}{|c|c|c|}
\hline $\mathbf{R}_{\mathbf{j t}}$ & $=$ & Share of $j^{\text {th }}$ output in total revenue \\
\hline Qjt & $=$ & Output 'j' \\
\hline $\mathbf{S}_{\mathbf{j t}}$ & $=$ & Share of $i^{\text {th }}$ input in total input cost \\
\hline $\mathbf{X}_{\mathbf{i t}}$ & $=$ & input 'i' \\
\hline Pit & $=$ & Price of $i^{\text {th }}$ in period ' $t$ ' \\
\hline
\end{tabular}

$\square$ By specifying TOI $\mathrm{t}-1$, TIIt-1 and IPIt-1 equal to 1.00 in the initial year, the above equation provides the total output, total input, total factor productivity and input price indices for the specified period ' $t$ '.

Chain-linking index takes into account the changes in relative values/costs throughout the period of study. This procedure has the advantage that no single period plays a dominant role in determining the share weights and biases are likely to be reduced. The above equations provide the indices of total output, total input, and TFP for the specified year ' $\mathrm{t}$ '.

\section{Log linear production function}

The contribution of research and development $(\mathrm{R}$ and $\mathrm{D})$ in gross return from mango research (Y) was estimated through the various types of production function viz; multiple linear production function, CobbDouglas production function. Thus, the contribution of research and development in TFP (Y), were calculated by log linear production function. The functional relationship between output (Y) and factors which are taken model can be written as

$\ln Y=a+b_{1} \ln x_{1}+b_{2} \ln x_{2}+b_{3} \ln x_{3}+b_{4} \ln$ $\mathrm{x}_{4}+\mathrm{b}_{5} \ln \mathrm{x}_{5}+\mathrm{ut}$

Where,

\begin{tabular}{|c|c|l|}
\hline $\mathbf{Y}$ & $=$ & Total Factor Productivity index (TFP) \\
\hline $\mathbf{a}$ & $=$ & Constant term \\
\hline $\mathbf{x}_{1}$ & $=$ & Research investment $(₹ / h a)$ \\
\hline $\mathbf{x}_{2}$ & $=$ & Average rainfall $(\mathbf{m m} /$ year $)$ \\
\hline $\mathbf{x}_{3}$ & $=$ & Road density $(\mathbf{k m})$ \\
\hline $\mathbf{x}_{4}$ & $=$ & Villages electrified $($ No. $)$ \\
\hline
\end{tabular}

\begin{tabular}{|c|c|c|}
\hline $\mathbf{x}_{5}$ & $=$ & Rural literacy $(\%)$ \\
\hline $\mathbf{t}$ & $=$ & Time variable (years $\mathbf{1 , 2}, \mathbf{3} \ldots \mathbf{n})$ \\
\hline $\mathbf{u}$ & $=$ & Error term \\
\hline \\
$\left(\mathrm{b}_{1}, \quad \mathrm{~b}_{2}, \quad \mathrm{~b}_{3}, \quad \mathrm{~b}_{4} \quad\right.$ and $\quad \mathrm{b}_{5} \quad$ are $\quad$ regression \\
coefficients of respective variables)
\end{tabular}

\section{Marginal Return}

The time series data from the different years were used. Using the elasticity of TFP with respect to research and development investment, one can estimate the value of marginal product of research and development investment.

$\mathrm{EVMP}=\mathrm{b} \times(\mathrm{V} / \mathrm{I})$

Where,

\begin{tabular}{|l|c|l|}
\hline I & $:$ & Research investment \\
\hline B & $:$ & TFP Elasticity of researchinvestment \\
\hline V & $:$ & Value of production associated with TFP \\
\hline EVMP & $:$ & Estimated value of marginal product \\
\hline
\end{tabular}

Mango Research expenditure flexibility equals to the inverse of TFP elasticity with respect to research gives flexibility to research expenditure, $\mathrm{REF}=1 / \mathrm{bi}$ (Research elasticity)

\section{Results and Discussion}

\section{Tornqvist Total Factor Productivity Indices of Mango}

The result presented in Table 1 revealed that, in the Konkan region the average values of TII,TOI and TFP index of mango over the period of twenty years were 1.05, 1.85 and 1.77 , respectively. The value of the TOI reached its peak in the year 2017-18 (2.88) and its lowest value was in the year 2009-10 (1.13) as compared to the base year i. e., 1998-99. The value of TII, on the other hand reached its highest in the year 2002-03 (1.34) and lowest in the year 2014-15 (0.82). The TFP index of mango in the region was lowest 
as compared to the base year in 2009-10 which could be due to climatic fluctuations like phyan cyclone and also pest incidence in that year. The year after 2009-10 observed again increase in TFP index. This was mainly due to the fact that mango farmers were adopting package of practices given by the University.

It clearly indicated that, there is a contribution of technology in TFP growth even though the input indices decreasing while, it may take longer gestation period to reflect in compound growth rates of input, output and TFP of mango. Though the TFP index was showed promising for the study period it indicated that the inputs were efficiently allocated in mango cultivation. For all of the year the growth of output index was higher than 1.00 over a period of time. Total factor productivity measures the efficiency of all the inputs to a production process. Increase in TFP results usually from technological innovations and improvements.

In order to asses growth performance of TFP of mango in Konkan region Maharashtra, the compound growth rate of input (TII), output (TOI) and TFP indices were estimated for 20 years from 1998-99 to 2017-18 and for two periods viz., period I (1998-99 to 2007-08) and period II (2008-09 to 2017-18). The same has been presented in Table 4.7.

Table.1 Total Input, Total Output and TFP Indices of Mango in Konkan Region of Maharashtra

\begin{tabular}{|c|c|c|c|c|}
\hline Sr. No. & Year & TII & TOI & TFP \\
\hline 1 & 1998-99 & 1.00 & 1.00 & 1.00 \\
\hline 2 & 1999-00 & 1.21 & 1.36 & 1.12 \\
\hline 3 & 2000-01 & 0.89 & 1.44 & 1.62 \\
\hline 4 & 2001-02 & 1.04 & 1.81 & 1.74 \\
\hline 5 & 2002-03 & 1.34 & 2.10 & 1.57 \\
\hline 6 & 2003-04 & 1.19 & 1.98 & 1.66 \\
\hline 7 & 2004-05 & 1.07 & 1.60 & 1.50 \\
\hline 8 & 2005-06 & 0.93 & 2.05 & 2.20 \\
\hline 9 & 2006-07 & 1.19 & 1.97 & 1.66 \\
\hline 10 & 2007-08 & 1.06 & 2.81 & 2.65 \\
\hline 11 & 2008-09 & 1.11 & 1.82 & 1.64 \\
\hline 12 & 2009-10 & 1.08 & 1.13 & 1.05 \\
\hline 13 & 2010-11 & 1.13 & 1.40 & 1.24 \\
\hline 14 & 2011-12 & 0.87 & 1.67 & 1.92 \\
\hline 15 & $2012-13$ & 0.96 & 1.82 & 1.90 \\
\hline 16 & 2013-14 & 0.99 & 2.68 & 2.71 \\
\hline 17 & 2014-15 & 0.82 & 1.40 & 1.71 \\
\hline 18 & $2015-16$ & 1.19 & 1.72 & 1.45 \\
\hline 19 & 2016-17 & 0.99 & 2.35 & 2.37 \\
\hline 20 & $2017-18$ & 0.84 & 2.88 & 3.43 \\
\hline \multicolumn{2}{|c|}{ Average } & 1.05 & 1.85 & 1.77 \\
\hline
\end{tabular}

Note: $\mathrm{TII}=$ Total Input Index

TOI $=$ Total Output Index

TFP= Total Factor Productivity 
Table.2 Compound Annual Growth Rates of TII, TOI and TFP of Mango

\begin{tabular}{|c|l|c|c|c|}
\hline \multirow{2}{*}{ Sr. No. } & \multicolumn{1}{|c|}{ Period } & \multicolumn{3}{|c|}{ CGR (\%) } \\
\cline { 3 - 5 } & & TII & TOI & TFP \\
\hline $\mathbf{1}$ & Period I (1998-99 to 2007-08) & 0.36 & $8.35^{* * *}$ & $7.96^{* *}$ \\
\hline $\mathbf{2}$ & Period II (2008-09 to 2017-18) & -1.81 & $6.34^{*}$ & $8.3^{* *}$ \\
\hline $\mathbf{3}$ & Overall Period (1998-99 to 2017-18) & $-0.86^{*}$ & $2.05^{*}$ & $2.93^{* *}$ \\
\hline
\end{tabular}

Note: ***,** and $*$ Significant 1,5 and 10 per cent, respectively

Note: $\mathrm{TII}=$ Total Input Index

TOI $=$ Total Output Index

TFP= Total Factor Productivity

Table.3 Estimates of TFP Growth of Mango

\begin{tabular}{|c|l|c|}
\hline Sr. No. & \multicolumn{1}{|c|}{ Variables } & Coefficients \\
\hline $\mathbf{1 .}$ & (a) Intercept & $-7.75^{* * * *}$ \\
& & $(2.20)$ \\
\hline $\mathbf{2 .}$ & $\left(\mathrm{X}_{1}\right)$ Research investment $(₹)$ & $0.18^{* * *}$ \\
& & $(0.05)$ \\
\hline $\mathbf{3 .}$ & $\left(\mathrm{X}_{2}\right)$ Rainfall $(\mathrm{mm} / \mathrm{year})$ & $0.55^{* * *}$ \\
& & $(0.22)$ \\
\hline $\mathbf{4 .}$ & $\left(\mathrm{X}_{3}\right)$ Road Density $(\mathrm{km})$ & $0.63^{*}$ \\
& & $(0.15)$ \\
\hline $\mathbf{5 .}$ & $\left(\mathrm{X}_{4}\right)$ Rural Literacy $(\%)$ & $2.05^{* *}$ \\
& & $(0.58)$ \\
\hline $\mathbf{6 .}$ & $\left(\mathrm{X}_{5}\right)$ No. of Villages Electrified (No.) & -0.33 \\
& & $(0.39)$ \\
\hline $\mathbf{7 .}$ & $\mathrm{R}^{2}$ & 0.84 \\
\hline $\mathbf{8 .}$ & 'F' value & $29.80^{* * *}$ \\
\hline $\mathbf{9 .}$ & $\mathrm{N}$ (No. of observations) & 20 \\
\hline
\end{tabular}

Note : ***, ** and $*$ Significant 1,5 and 10 per cent, respectively

(Figures in parentheses are standard errors)

Table.4 Estimated Value of Marginal Product of Mango

\begin{tabular}{|c|c|c|c|}
\hline Sr. No. & Year & Research cost $(\mathbf{₹} / \mathbf{h a})$ & Output Associated with TFP (₹ /ha) \\
\hline $\mathbf{1}$ & $1998-99$ & 469.63 & 25307.38 \\
\hline $\mathbf{2}$ & $1999-00$ & 405.96 & 26208.71 \\
\hline $\mathbf{3}$ & $2000-01$ & 247.16 & 28127.68 \\
\hline $\mathbf{4}$ & $2001-02$ & 180.18 & 30028.82 \\
\hline $\mathbf{5}$ & $2002-03$ & 91.49 & 41940.95 \\
\hline $\mathbf{6}$ & $2003-04$ & 112.06 & 40319.11 \\
\hline $\mathbf{7}$ & $2004-05$ & 94.61 & 30780.29 \\
\hline $\mathbf{8}$ & $2005-06$ & 89.33 & 3674.27 \\
\hline $\mathbf{9}$ & $2006-07$ & 76.90 & 47643.12 \\
\hline
\end{tabular}




\begin{tabular}{|l|c|c|c|}
\hline $\mathbf{1 0}$ & $2007-08$ & 75.82 & 52178.06 \\
\hline $\mathbf{1 1}$ & $2008-09$ & 73.63 & 40007.71 \\
\hline $\mathbf{1 2}$ & $2009-10$ & 62.81 & 33480.14 \\
\hline $\mathbf{1 3}$ & $2010-11$ & 75.69 & 35792.93 \\
\hline $\mathbf{1 4}$ & $2011-12$ & 117.87 & 38151.61 \\
\hline $\mathbf{1 5}$ & $2012-13$ & 119.6 & 28917.67 \\
\hline $\mathbf{1 6}$ & $2013-14$ & 127.54 & 47284.37 \\
\hline $\mathbf{1 7}$ & $2014-15$ & 73.45 & 27884.42 \\
\hline $\mathbf{1 8}$ & $2015-16$ & 76.43 & 56874.44 \\
\hline $\mathbf{1 9}$ & $2016-17$ & 73.39 & 70715.38 \\
\hline $\mathbf{2 0}$ & $2017-18$ & 81.62 & 67808.40 \\
\hline & Total & $\mathbf{2 7 2 5 . 1 8}$ & $\mathbf{8 0 6 1 6 4 . 4 8}$ \\
\hline & Mean & $\mathbf{1 3 6 . 2 6}$ & $\mathbf{4 0 3 0 8 . 2 2}$ \\
\hline & EVMP & $\mathbf{5 3 . 2 5}$ & \\
\hline & REF & $\mathbf{5 . 5 6}$ & \\
\hline
\end{tabular}

A perusal of table revealed that at the overall period of study (1998-99 to 2017-18) TFP increased at 2.93 per cent per annum. During the same period, output index grew by 2.05 per cent per annum and input index declined at the rate of 0.86 per cent per annum. In sub periods also the results were more revealing. The input index grew at the rate of 0.36 per cent per annum during period I, while output index also grew at the rate of 8.35 per cent per annum.

The TFP index has increased at the rate of 7.96 per cent per annum. But interestingly in the period II input index decline at the rate of 1.81 per cent per annum whereas, output index grew at the rate of 6.34 per cent per annum and TFP index witnessed growth of 8.3 per cent per annum significantly increased during the period II. The improvement in the total factor productivity was due to non- input factors such research investment and extension efforts. The Dr. Balasaheb Sawant Konkan Krishi Vidyapeeth, Dapoli has released a number of new improved varieties to increase productivity of mango. Hence, Agricultural Universities played a crucial role in growth of TFP of mango.
However, for overall period TFP of mango was positive and significant at 5 per cent level of significance. Hence, it confirmed that the farmers have adopted the varieties and technology package of mango at maximum level. Thus the hypothesis stated that, "Increase in total factor productivity indicates the contribution of technology" has been proved. The results were in consonance with the findings of Rosegrant and Everson (1992), Khobarkar (2005), Thorat et al., (2006) Chand et al., (2012) and Singh et al., (2017).

\section{Sources of Total Factor Productivity (TFP) Growth in Mango}

The growth rate in TFP was further analyzed in terms to quantify the contributions of various factors to TFP growth. The estimated effect of various factors which include research investment, rainfall, road density, rural literacy, no. of villages electrified etc. (Table 3)

Estimates of regression coefficients which measure the effect of various sources of TFP, were used to compute elasticity of TFP with respect to research investment and to assess the impact of research. The results indicated that, research investment (0.18) constituted a 
significant source of TFP growth in mango, implying that each one per cent increase in the investment would bring about 0.18 per cent increase in the TFP of mango in Konkan region of Maharashtra state. Natural resource and infrastructural variables were important sources of TFP in mango. Among natural resources rainfall $(0.55)$ and in infrastructural variables road density (0.63) had played a significant role in enhancing the TFP in mango. Road density would induce inputoutput market interface and created a suitable environment for adoption of technology. Rural literacy (2.05) has significantly contributed to TFP growth in mango. Literacy had a positive and significant relation with mango productivity and a strong link existed between literacy and farm modernization. Literacy emerged as an important source of growth in adoption of technology and use of modern inputs like machines, fertilizers etc. Contribution of literacy, through TFP, was substantial on yield growth and domestic supply. As future agriculture will increasingly be science-led and will require modern economic management, high return to investment on education is expected. The no. of villages electrified $(-0.33)$ was taken as proxy. It turned out negative and nonsignificant indicating that shortage and uneven power supply has affected inversely on the total factor productivity in mango.

The estimated $\mathrm{R}^{2}$ value was 0.84 indicating that 84 per cent of variation in TFP jointly explained by the five factors included in the model. The ' $F$ ' value was statically significant indicating good fit of the model.

\section{Rate of Returns to Research and Development}

To estimate the marginal value product the regression coefficients should be positive and statistically significant. Thus, in this study, the regression coefficient of research investment of mango was found significant. The inverse of TFP elasticity with respect to research gives flexibility to research expenditure. The estimated value was 5.56 which mean that to achieve one per cent increase in TFP, the investments in mango research needs to be increased by 5.56 per cent. Estimated value of marginal returns was 53.25. It indicates that an additional investment of one rupee in mango research generated additional income of ₹ 53.25. The inverse of TFP elasticity to research gives flexibility to research investment. The estimated value was 5.56 which means that to achieve one per cent growth in TFP, the investments in research need to be increased by 5.56 per cent for mango in Konkan region of Maharashtra.

\section{References}

Alexender, 2007. Productivity growth of agriculture in Vidarbha. Unpublished Ph.D. thesis submitted to Dr. P.D.K.V., Akola.

Christensen, L.R., 1975. Concept and measurement of agricultural productivity. American Journal of Agricultural Economics. Vol. 57(5) : 910-915.

Chand R., P. Kumar and S. Kumar, 2012. Total factor productivity and returns to public investment on agricultural research in India, NCAP, New Delhi, Agricultural Economics Research Review, 25(2):181-194.

Choudhari, S. A., A. S. Jangale, S. S. Lande and R. A. Vilhekar, 2020. Role of Technological Change in Enhancing The Income of Rainfed Farmers - A Study of Bajra Crop in Western Maharashtra. International Journal of Chemical Studies, 8(1): 406-409.

Khobarkar, V., 2005. Economic analysis of total factor productivity in agriculture in Konkan region (M.S.). Unpublished 
Ph.D. thesis submitted toDr. BSKKV, Dapoli.

Suresh, K. and M. G. Chandrakanth, 2015. Total factor productivity and returns to investment in Ragi (finger millet) crop research in Karnataka state, India. Indian Journal of Economics and Development, 3(3): 199-205.

Singh, N., A. K. Leua, P. C. Meena and K. S. Patel. 2017. Impact of total factor productivity and return to investment on research for sustainable agriculture growth: A case study of South Gujarat region. Indian Journal of Economics and Development, 13(1):111-122.

Thorat, V. A., S. N. Tilekar, J. S. Dhekale and H. K. Patil, 2006. Total factor productivity in horticultural crops in Konkan region of Maharashtra. Agricultural Economics Research Review, 19: 113-120.

\section{How to cite this article:}

Amruta S. Jangale, R. B. Hile and Rathod, P. C. 2021. Total Factor Productivity Growth and Returns from Mango Research in Konkan Region of Maharashtra. Int.J.Curr.Microbiol.App.Sci. 10(01): 2060-2068. doi: https://doi.org/10.20546/ijcmas.2021.1001.237 